\title{
Biology and Thermal Requirements of Euseius scutalis (Athias-Henriot) Fed on Three Pest Prey Types and Pollen
}

\author{
M. A. Nawar \\ Animal Pest Unit, Plant Protection Department, Desert Research Center.
}

\begin{abstract}
Biological aspects and thermal requirements of Euseius scutalis (Athias-Henriot) fed on Tetranychus urticae Koch, Eutetranychus orientalis (Klein), Bemisia tabaci (Genn.) and date palm pollen were studied under laboratory conditions. The female life span duration was $(35.3,29.95,22.6),(40.1,29.9,21),(38.7,30.9,22.8)$ and $(41.9,29.920 .6)$ days when fed on T. urticae, E. orientalis B. tabaci and pollen at 20,25 and $30^{\circ} \mathrm{C}$, respectively. Corresponding developmental rates were $0.028,0.033$ and 0.44 on $T$. urticae, $0.025,0.033$ and 0.048 on E. orientalis, $0.026,0.032$ and 0.044 on $B$. tabaci and $0.024,0.033$ and 0.049 on pollens per day at same temperatures. These rates were fitted to linear equation with $\mathrm{R}^{2}$ of $0.958,0.98,0.975$, and 0.984. Male developmental times, rates and thermal requirement for development were very similar. Fecundity per female was 32.8, 38.5, 44.2; 27.2, 35.6, 28.2; 31.4, 24.6, 17 and 31.8, 33.8, 44.4 eggs/female over tested temperatures and diets, respectively. Pollen recorded lowest thermal requirements for E. scutalis different stages with highest daily ovipostion; while $T$. urticae recorded the highest (especially for females) with similar total fecundity with pollen. Obtained results suggest that the best food source for the E. scutalis was pollen followed by T. urticae then E. orientalis and finally B. tabaci. The best tested temperature was $30^{\circ} \mathrm{C}$. The wide range of food sources and temperature range may explain the wide spread of this phytoseiid predator in the Egyptian agricultural environment where it is found on most plants. Enhancement of occurrence of this mite over different plants may reduce to some extend the need of applying pesticides.
\end{abstract}

Key words: Euseius scutalis; Bemisia tabaci; Tetranychus urticae; Eutetranychus orientalis; Temperature, Thermal requirements, Development.

\section{INTRODUCTION}

Many studies on predacious mites of the family Phytoseiidae are worldwide and important natural enemies of different phytophagous pests on a variety of plants. They are important part of mites' natural control and can be used in applied bio-control of mites and some insects (Gerson et al., 2003; Fouly et al., 2011and Mostafa, 2012). Phytoseiid mites were classified according to their life-style into four categories and sub ones. Euseius scutalis (AthiasHenriot) fits the fourth category as pollen feeding generalist predators. Consideration is given to the relative importance of each of these types in biological control and pest management programs (McMurtry and Croft, 1997; Luh and Croft, 2001 and McMurtry et al., 2013). The role of particularistic and generalist possible predators in the control of phytophagous arthropod populations has been reviewed extensively (Schausberger and Walzer, 2001).

Persistence of generalist predatory mites on vegetation with a scarcity or absence of prey is a requirement for successful biocontrol tricks of herbivore mites. These mites feeds to not only on herb feeding mites but have also the ability to feed on some other sources of food and reproduce more rapidly on a variety of plant pollens (Abou-Setta and Childers, 1987; Gnanvossou et al., 2005; Emmert et al., 2008 and Fouly et al., 2011). Certain herb pollens have been easily used for mass-rearing phytoseiids in the laboratory for experimental purposes or field release.

Genus Euseius is optional predators, which are not only mite potential predators but also, have the ability to feed on other source of food such as white take flight, small arthropods and pollens (Fouly and Hassan, 1991 and Abou-Awad et al., 1992).

The major impact of generalists, such as Euseius species, is at low population densities of spider mites, where they may prevent the widespread colonization and increase of the infestation species (McMurtry, 1992). Also, field statement evidently showed that $E$. scutalis is generally found in association with tetranychid mite species, scale insects, ovum and various immature levels of other insects as well as plant pollen (Yousef and El-Halawany, 1982; McMurtry et al., 1992; Al-Shammery, 2010, 2011).

Temperature is a major abiotic factor affecting the dynamics of arthropod pests and their natural enemies (Huffaker et al., 1999). The understanding of insect and mite different types to climatic conditions performs an essential role in pest management to forecast the timing of development, reproduction and dormancy or migration (Gorji et al., 2008).

Previous studies in Egypt, indicated that $E$. scutalis definitely is the most considerable and vastly disseminate phytoseiid mite (El-Laithy and Fouly, 1992; Abou-Awad et al., 1998 and Fouly et al., 
2013). E. scutalis was observed feeding on spider mites, eggs and small insect species that live in the same habitat. As a result, E. scutalis is recognized as one of the generalist that can feed on a variety of food source.

The aim of this study was to increases our knowledge about E. scutalis biology when reared under laboratory conditions on three pest mites and pollen under different temperatures.

\section{MATERIALS AND METHODS}

\section{Collection of mites:}

E. scutalis and the spider mite Tetranychus urticae Koch were collected from leaves of blackberry, Rubus ursinus Cham \& Schldl infested plants at the farm of the Faculty of Agriculture, AlAzhar University, in Cairo.

\section{Culture of $\boldsymbol{E}$. scutalis:}

The predatory mite was reared on a freshly mulberry leaves, Morus alba placed upside down on cotton pads in plastic trays. Water was added when needed to maintain suitable moisture. An abundance of $T$. urticae stages was offered daily to the predator as a main source of food. Trays were maintained at $25 \pm 2{ }^{\circ} \mathrm{C}$ and $70 \pm 5 \%$ R.H. Newly deposited eggs of the predator were transferred solitary to experimental units each consisted of mulberry leaf disc $2.5 \mathrm{~cm}$ diameter placed lower side up on water soaked cotton bed $(10 \mathrm{~cm}$ diameter and $1 \mathrm{~cm}$ thick) in a Petri dish (12 $\mathrm{cm}$ diameter). The borders of the leaves were surrounded by barrier (a mixture of Canada balsam, castor and citronella oils). The number of eggs laid was counted daily. The observations continued allover predator life span at 20,25 and $30 \pm 2^{\circ} \mathrm{C}$. A total of 25 replicates per temperature or diet were prepared.

\section{Experimental procedures:}

T. urticae and Eutetranychus orientalis (Klein) motil stages, the white fly, Bemisia tabaci nymphs (which was collected from cabbage Brassica oleracea var. capitata L.) and date palm pollens were considered as food sources. All groups were incubated at 20,25 and $30 \pm 1{ }^{\circ} \mathrm{C}$ and $75 \pm 3 \%$ R. H.

Thermal requirements for different developmental stages of E. scutalis, were calculated using Microsoft Excel application. Developmental rates were estimated as $1 /$ developmental times. Using linear regression $(\mathrm{Y}=\mathrm{a}+\mathrm{bX})$ for obtained developmental rates over tested temperatures (X) developmental threshold $\left(\mathrm{t}_{\mathrm{o}}{ }^{\circ} \mathrm{C}\right)$ and thermal degree days ( $\mathrm{K}$ value) (Physiological time) was calculated.

\section{RESULTS AND DISCUSSION}

\section{Thermal effect and requirements for development:}

Obtained results for developmental durations, rates and thermal requirements are presented in Tables (1-3) for female and male, respectively.

Developmental times over tested temperatures revealed negative relation with temperature increase; while developmental rates were positive. Female life span developmental time was, 35.3, 29.95 and 22.6 when fed on T. urticae; 40.1, 29.9 and 21 days when fed on E. orientalis; 38.7, 30.9 and 22.8 on $B$. tabaci and 41.9, 29.9 and 20.6 on data palm pollen at 20,25 and $30^{\circ} \mathrm{C}$, respectively. Corresponding rates were $0.028,0.033$ and 0.44 on $T$. urticae, $\cdot .025,0.033$ and 0.048 on E. orientalis; $0.026,0.032$ and 0.044 on B. tabaci and $0.024,0.033$ and 0.049 on pollens per day. These rates were fitted to linear equation with $\mathrm{R}^{2}$ of $0.958,0.98,0.975$, and 0.984 . Total developmental thermal requirement was $628.173,440.89,554.943$ and 405.23 degree days over thermal threshold of $2.812,9.422,6.12$ and $10.7^{\circ} \mathrm{C}$. Male developmental times, rates and thermal requirement for total development were very similar. Total female life cycle was 9.9, 5.8, 7.85; 11.5, 8.8, 5.7; 10.9, 8.3, 5.8 and 9.9, 6.8, 4.6 days for females at tested $(20,25$ and $30^{\circ} \mathrm{C}$ ). Corresponding values for male were; $8.9,6.5$, $4.4 ; 10.4,7.5,5.3 ; 8.9,7.5,5.5$ and $9.1,5.7,4.5$ days, respectively (Table 3 ).

E. scutalis female longevity was 27.12 days when reared on T. urticae at $25^{\circ} \mathrm{C}$ (El-Laithy and Fouly, 1992). Female longevity and life span of E. scutalis reared on nymphs of $T$. urticae were 30.68 and 27.25 days, at 25 and $30^{\circ} \mathrm{C}$, respectively (Osman et al., 2013), while same parameters were reported as 29.57, 22.79 and 18.54 days, at 25,20 and $30^{\circ} \mathrm{C}$, respectively when reared on pollens by Saleh et al. (2015). Differences in findings regarding total developmental duration may be due to differences in prey and the experimented temperature degrees.

Data in (Table 4) indicated that, mean number of eggs deposited per E. scutalis female was 32.8, 38.5, $44.2 ; 27.2,35.6,28.2 ; 31.4,24.6,17$ and 31.8, 33.8, 44.4 eggs over tested when fed on $T$. urticae, $E$. orientalis, B. tabaci and pollens at 20,25 and $30^{\circ} \mathrm{C}$ temperatures, respectively. Similar results were obtained by Allawi (1991) who found that E. scutalis fed on castor bean, corn and pollen collected by honey bees laid a total number of 52.20, 33.50 and 40.53 eggs per female with a daily rate of $2.10,1.43$ and 1.98 eggs, respectively. Moreover, El-Laithy and Fouly, 1992 found that $E$. scutalis and A. swirskii fed on T. urticae laid 13.5 and 27.8 eggs per female, 
Table (1): Mean duration in days of E. scutalis immature stages fed on T. urticae, E. orientalis, B. tabaci and date palm pollen at different temperatures

\begin{tabular}{|c|c|c|c|c|c|c|c|c|c|}
\hline \multirow[b]{2}{*}{ Variable } & \multirow{2}{*}{$\begin{array}{l}\text { Temp. } \\
\left({ }^{\circ} \mathrm{C}\right)\end{array}$} & \multicolumn{4}{|c|}{ Total immature } & \multicolumn{4}{|c|}{ Life cycle } \\
\hline & & $\begin{array}{c}T . \\
\text { urticae }\end{array}$ & $\begin{array}{c}E . \\
\text { orientalis }\end{array}$ & $\begin{array}{c}\text { B. } \\
\text { tabaci }\end{array}$ & Pollens & $\begin{array}{c}T . \\
\text { urticae }\end{array}$ & $\begin{array}{c}E . \\
\text { orientalis }\end{array}$ & $\begin{array}{c}B . \\
\text { tabaci }\end{array}$ & Pollens \\
\hline \multirow{3}{*}{ Duration } & 20 & 4.8 & 6.4 & 8.4 & 7.3 & 9.9 & 11.5 & 10.9 & 9.9 \\
\hline & 25 & 4.2 & 4.7 & 6.5 & 5.3 & 7.85 & 8.8 & 8.3 & 6.8 \\
\hline & 30 & 3.2 & 3.1 & 4.4 & 3.3 & 5.8 & 5.7 & 5.8 & 4.6 \\
\hline \multirow{3}{*}{ Rate } & 20 & 0.208 & 0.156 & 0.119 & 0.137 & 0.101 & 0.087 & 0.092 & 0.101 \\
\hline & 25 & 0.238 & 0.213 & 0.154 & 0.189 & 0.127 & 0.114 & 0.12 & 0.147 \\
\hline & 30 & 0.313 & 0.323 & 0.227 & 0.303 & 0.172 & 0.175 & 0.172 & 0.217 \\
\hline \multirow{5}{*}{$\begin{array}{l}\text { Regression } \\
\text { values }\end{array}$} & Intercept & -0.007 & -0.185 & -0.104 & -0.206 & -0.045 & -0.096 & -0.073 & -0.136 \\
\hline & Slope & 0.01 & 0.017 & 0.011 & 0.017 & 0.007 & 0.009 & 0.008 & 0.012 \\
\hline & $\mathrm{t}_{0}\left({ }^{\circ} \mathrm{C}\right)$ & 0.714 & 11.14 & 9.595 & 12.379 & 6.289 & 10.834 & 9.107 & 11.669 \\
\hline & $\begin{array}{c}\mathrm{K} \text { (Degree } \\
\text { days) }\end{array}$ & 96 & 60.121 & 92.4 & 60.225 & 140.049 & 113.017 & 123.961 & 85.925 \\
\hline & $\mathrm{R}^{2}$ & 0.942 & 0.967 & 0.959 & 0.955 & 0.978 & 0.95 & 0.973 & 0.986 \\
\hline
\end{tabular}

Table (2): Mean duration in days of adult female longevity and life span of E. scutalis fed on T. urticae, E. orientalis, B. tabaci and date palm pollen at different temperatures.

\begin{tabular}{|c|c|c|c|c|c|c|c|c|c|}
\hline \multirow[b]{2}{*}{ Variable } & \multirow{2}{*}{$\begin{array}{l}\text { Temp } \\
\left({ }^{\circ} \mathrm{C}\right)\end{array}$} & \multicolumn{4}{|c|}{ Total immatures } & \multicolumn{4}{|c|}{ Life cycle } \\
\hline & & $\begin{array}{c}T . \\
\text { urticae }\end{array}$ & $\begin{array}{c}\text { E. } \\
\text { orientalis }\end{array}$ & $\begin{array}{c}B . \\
\text { tabaci }\end{array}$ & Pollen & $\begin{array}{c}T . \\
\text { urticae }\end{array}$ & $\begin{array}{c}E . \\
\text { orientalis }\end{array}$ & $\begin{array}{c}B . \\
\text { tabaci }\end{array}$ & Pollens \\
\hline \multirow{3}{*}{ Duration } & 20 & 4.8 & 6.4 & 8.4 & 7.3 & 9.9 & 11.5 & 10.9 & 9.9 \\
\hline & 25 & 4.2 & 4.7 & 6.5 & 5.3 & 7.85 & 8.8 & 8.3 & 6.8 \\
\hline & 30 & 3.2 & 3.1 & 4.4 & 3.3 & 5.8 & 5.7 & 5.8 & 4.6 \\
\hline \multirow{3}{*}{ Rate } & 20 & 0.208 & 0.156 & 0.119 & 0.137 & 0.101 & 0.087 & 0.092 & 0.101 \\
\hline & 25 & 0.238 & 0.213 & 0.154 & 0.189 & 0.127 & 0.114 & 0.12 & 0.147 \\
\hline & 30 & 0.313 & 0.323 & 0.227 & 0.303 & 0.172 & 0.175 & 0.172 & 0.217 \\
\hline \multirow{5}{*}{$\begin{array}{l}\text { Regression } \\
\text { values }\end{array}$} & Intercept & -0.007 & -0.185 & -0.104 & -0.206 & -0.045 & -0.096 & -0.073 & -0.136 \\
\hline & Slope & 0.01 & 0.017 & 0.011 & 0.017 & 0.007 & 0.009 & 0.008 & 0.012 \\
\hline & $\mathrm{t}_{0}\left({ }^{\circ} \mathrm{C}\right)$ & 0.714 & 11.14 & 9.595 & 12.379 & 6.289 & 10.834 & 9.107 & 11.669 \\
\hline & $\begin{array}{c}\mathrm{K} \text { (Degree } \\
\text { days) }\end{array}$ & 96 & 60.121 & 92.4 & 60.225 & 140.049 & 113.017 & 123.961 & 85.925 \\
\hline & $\mathrm{R}^{2}$ & 0.942 & 0.967 & 0.959 & 0.955 & 0.978 & 0.95 & 0.973 & 0.986 \\
\hline
\end{tabular}

Table (3): Mean duration in days of adult male longevity and life span of E. scutalis fed on T.urticae, E. orientalis, B. tabaci and date palm pollen at different temperatures.

\begin{tabular}{|c|c|c|c|c|c|c|c|c|c|}
\hline \multirow[b]{2}{*}{ Variable } & \multirow{2}{*}{$\begin{array}{c}\text { Temp. } \\
\left({ }^{\circ} \mathrm{C}\right)\end{array}$} & \multicolumn{4}{|c|}{ Total immatures } & \multicolumn{4}{|c|}{ Life cycle } \\
\hline & & $\begin{array}{c}T . \\
\text { urticae }\end{array}$ & $\begin{array}{c}E . \\
\text { orientalis }\end{array}$ & $\begin{array}{c}B . \\
\text { tabaci }\end{array}$ & Pollen & $\begin{array}{c}T . \\
\text { urticae }\end{array}$ & $\begin{array}{c}E . \\
\text { orientalis }\end{array}$ & $\begin{array}{c}B . \\
\text { tabaci }\end{array}$ & Pollens \\
\hline \multirow{3}{*}{ Duration } & 20 & 19.6 & 24 & 25.8 & 29.2 & 28.5 & 34.4 & 34.7 & 38.3 \\
\hline & 25 & 16.8 & 19.4 & 19.4 & 19.4 & 24.125 & 25.4 & 25.4 & 25.1 \\
\hline & 30 & 10.6 & 13.6 & 16 & 13.6 & 16.2 & 19.3 & 22.7 & 17.8 \\
\hline \multirow{3}{*}{ Rate } & 20 & 0.051 & 0.042 & 0.039 & 0.034 & 0.035 & 0.029 & 0.029 & 0.026 \\
\hline & 25 & 0.06 & 0.052 & 0.052 & 0.052 & 0.041 & 0.039 & 0.039 & 0.04 \\
\hline & 30 & 0.094 & 0.074 & 0.063 & 0.074 & 0.062 & 0.052 & 0.044 & 0.056 \\
\hline \multirow{5}{*}{$\begin{array}{l}\text { Regression } \\
\text { values }\end{array}$} & Intercept & -0.04 & -0.024 & -0.008 & -0.045 & -0.021 & -0.017 & -0.001 & -0.034 \\
\hline & Slope & 0.004 & 0.003 & 0.002 & 0.004 & 0.003 & 0.002 & 0.002 & 0.003 \\
\hline & $\mathrm{t}_{0}\left({ }^{\circ} \mathrm{C}\right)$ & 9.235 & 7.556 & 3.545 & 11.481 & 7.7 & 7.376 & 0.441 & 11.462 \\
\hline & $\begin{array}{c}\mathrm{K} \text { (Degree } \\
\text { days) }\end{array}$ & 230.84 & 313.84 & 421.22 & 254.56 & 375.36 & 439.68 & 656.4 & 332.55 \\
\hline & $\mathrm{R}^{2}$ & 0.89 & 0.954 & 0.998 & 0.995 & 0.917 & 0.997 & 0.953 & 0.997 \\
\hline
\end{tabular}


Table (4): Fecundity of E. scutalis on three tested temperatures.

\begin{tabular}{|c|c|c|c|c|c|}
\hline Variable & Temp. $\left({ }^{\circ} \mathrm{C}\right)$ & T. urticae & E. orientalis & B. tabaci & pollens \\
\hline \multirow{3}{*}{$\begin{array}{l}\text { Mean number of } \\
\text { eggs/female }\end{array}$} & 20 & 32.8 & 27.2 & 31.4 & 31.8 \\
\hline & 25 & 38.5 & 35.6 & 24.6 & 33.8 \\
\hline & 30 & 44.2 & 28.2 & 17 & 44.4 \\
\hline \multirow{3}{*}{ Eggs/female/day } & 20 & 1.7 & 1.2 & 1.7 & 1.8 \\
\hline & 25 & 2.4 & 2.4 & 1.4 & 2.7 \\
\hline & 30 & 3.1 & 2.8 & 1.2 & 5.3 \\
\hline
\end{tabular}

respectively. Feeding on B. tabaci only, E. scutalis female laid an average of 1.0 egg per day (Fouly and Hassan, 1991). Osman et al. (2013) found that $E$. scutalis number of eggs deposited per female was 31.93, 28.63 and 24.3, when fed on palm pollens, $T$. urticae and B. tabaci. Feeding on B. tabaci only, female mite of E. scutalis laid an average of 28.0, 22.93 and 19.0 eggs per day at 20,25 and $30^{\circ} \mathrm{C}$, respectively (Saleh et al., 1991).

\section{Thermal Requirements:}

Thermal requirements for E. scutalis total immature development was lowest at $E$. orientalis and pollen and maximum on T. urticae. Similarly, during adult female longevity lowest value was on pollen and maximum was on T. urticae. For female life span lowest value was on pollen and maximum was on B. abaci. In the mean time Total fecundity was highest at $T$. urticae and pollen, while lowest was on B. abaci. Mean daily oviposition was highest on pollen fowled by $E$. orientalis and B. abaci, respectively (Tables 1 to 4 ).

Obtained results suggest that the best food source for the E. scutalis was pollens followed by T. urticae then $E$. orientalis and finally $B$. tabaci. The best tested temperature was $30^{\circ} \mathrm{C}$. The wide range of food sources and temperature range may explain the wide spread of this phytoseiid predator in the Egyptian agricultural environment where it is found on most plants. Enhancement of occurrence of this mite over different plants may reduce to some extend the need of applying pesticides.

\section{REFERENCES}

Abou-Awad, B. A.; Reda, A. S. and Elsawi, S. A. 1992. Effects of artificial and natural diets on the development and reproduction of two phytoseiid mites Amblyseius gossipi and Amblyseius swirskii (Acari: Phytoseiidae). Insect Sci. Appl., 13: 441-445.

Abou-Awad, B. A.; El-Sherif, A. A; Hassan, M. F. and Abou-Elela, G. M. 1998. Studies on development, longevity, fecundity and predation of Amblyseius olivi Nasr and Abou- Awad (Acari: Phytoseiidae) on various kinds of prey and diets. J. Plant Dis. Prot., 105: 538-544.
Abou-Setta, M. and Childers, C. C. 1987. Biology of Euseius mesembrinus (Acari: Phytoseiddae): Life tables and life tables on ice plant pollen at different temperatures with notes on behavior and food range. Exp. Applied Acarol., 3: 123-130.

Al-Shammery, K. A. 2010. Different biological aspects of the predaceous mite Euseius scutalis (Athis-Henroit) and the effects due to feeding on three tetranychid mites in Saudi Arabia. Asian J. Biol. Sci., 3: 77-84.

Al-Shammery, K. A. 2011. Plant pollen as an alternative food source for rearing Euseius scutalis (Acari: Phytoseiidae) in Hail, Saudi Arabia. J. Entomol., 8: 365-374.

Allawi, T. F. 1991. Biological and ecological studies on indigenous and introduced phytoseiid mites: 1 . Mass rearing and study of the effect of different pollen and other plant derivatives on the fecundity and longevity of Euseius scutalis (A.-H.). Dirasat, 18: 57-67.

El-Laithy, A. Y. M. and Fouly, A. H. 1992. Life table parameters of the two phytoseiid predators Amblyseius scutalis (Athia-Henriot) and Swirikii A. H. (Acari, Phytoseiidae) in Egypt. J. Applied Entomol., 113: 8-12.

Emmert, C. J.; Russell, F.; Mizell, I.; Andersen, P. C.; Frank, J. H. and Stimac, J. 2008. Effects of contrasting diets and temperatures on reproduction and prey consumption by Proprioseiopsis asetus (Acari: Phytoseiidae). Exp. Applied Acarol., 44: 11-26.

Fouly, A. H. and Hassan, M. H. 1991. Effect of crowding and food level on the predaceous mite, Amblyseius gossipi El-Badry fed on white fly Bemicia tabaci (Genn). Bull. Zool. Sci. Egypt, 40: 141-146.

Fouly, A. H.; Al-Deghairi, M. A. and Abdel Baky, N. F. 2011. Biological aspects and life tables of Typhlodromips swirskii (Acari: Phytoseiidae) fed Bemisia tabaci (Hemiptera: Aleyroididae). J. Entomol., 8: 52-62.

Fouly, A. H.; Nassar, O. A. and Osman, M. A. 2013. Biology and life tables of Esieus scutalis (A.-H.) reared on different kinds of food. J. Entomol., 10: 199-206.

Gerson, U.; Smiley, R. L. and Ochoa, R. 2003. Mites (Acari) for Pest Control. Blackwell Science, Oxford, UK. 
Gnanvossou, D.; Hanna, R.; Yaninek, J. S. and Toko, M. 2005. Comparative life history traits of three neotropical phytoseiid mites maintained on plantbased diets. Biol. Control, 35: 32-39.

Gorji, M. K.; Kamali, K.; Fathipour, Y. and Aghdam, H. R. 2008. Temperature-dependent development of Phytoseius plumifer (Acari: Phytoseiidae) on Tetranychus urticae (Acari: Tetranychidae). Syst. Appl. Acarol., 13: 172-181.

Huffaker, C. B.; Berryman, A. and Turchin. P. 1999. Dynamics and regulation of insect populations, pp.269-305. In C. B. Huffaker and A. P. Gutierrez (eds.), Ecological entomology, 2nd ed.Wiley, NewYork, NY.

Luh, H. K. and Croft, B. A. 2001. Quantitative classification of life-style types in predaceous phytoseiid mites. Exp. Applied Acarol., 25: 403424.

McMurtry, J. A. 1992. Dynamics and potential impact of generalist phytoseiids in agroecosysterns and possibilities for establishment of exotic species. Exp. Applied. Acarol., 14: 371-382.

McMurtry, J. A. and Croft, B. A.1997. Life styles of phytoseiid mites and their roles in biological control. Ann. Rev. Entomol., 42: 291-321.

McMurtry, J.A.; Moraes, G.J. De and Sourassou, N.F. 2013. Revision of the lifestyles of phytoseiid mites
(Acari: Phytoseiidae) and implications for biological control strategies. Sys. Appl. Acarol., 18 (4), 297-320.

Mostafa, E. S. M. 2012. Laboratory studies on Euseius metwallyi a predator of the spider mite Tetranychus urticae on fruit trees in Egypt (Acarina: Phytoseiidae: Tetranychidae). J. Entomol., 9: 107-114.

Osman, M. A.; Abou-Elella, G. M. and Tawfik, A. A. 2013. Temperature-Dependent development, life table parameters and predation rate of Euseius scutalis (A.-H.) fed on the two-spotted spider mite. ACARINES, 7: 11-17.

Saleh, E. B. Y.; Mostafa, M. A.; Desuky, W. M. H.; El-Kawas, H. M. G. 2015. Thermal Units of the Predatory Mite, Euseius scutalis (Athisa-Henriot) (Acari: Phytoseiidae) Fed on Crawlers of Bemisia tabaci (Genn.) (Hemiptera: Aleyrodidae). Egyptian Journal of Biological Pest Control, 25(3): 663-667.

Schausberger, P. and Walzer, A. 2001. Combined versus single species release of predaceous mites: Predator-predator interactions and pest suppression. Biol. Control, 20: 269-278.

Yousef, A. A. and El-Halawany, M. E. 1982. Effect of prey species on the biology of Amblyseius gossipi El-Badry (Acari: Mesostigmata: Phytoseiidae). Acarologia, 23: 113-117. 